\title{
Kava as a Pharmacotherapy of Anxiety Disorders: Promises and Concerns
}

Zachary Rivers ${ }^{1}$, Chengguo Xing $^{2}$ and Sreekanth Narayanapillai ${ }^{*}$

${ }^{1}$ College of Pharmacy, University of Minnesota, 308 Harvard St SE, Minneapolis, MN 55455, USA

${ }^{2}$ Department of Medicinal Chemistry, College of Pharmacy, University of Minnesota, 2231 th St SE, Minneapolis, MN 55455, USA

\begin{abstract}
Current standard pharmacotherapies for anxiety management come with a host of side-effects that may deter the patients from utilizing them. Kava, a traditional beverage from the South Pacific region, has been used as a natural medicine for centuries and has been hypothesized to contain anxiolytic properties. There are a few well-designed, randomly controlled trials that have evaluated the effectiveness of kava or its constituents against anxiety disorders. They have generally shown kava to be effective in managing the disease. However, there has been a serious concern about the hepatotoxic risk of kava, which greatly limits its anxiolytic development and application. This review attempts to summarize the recent anxiolytic trials using kava, the associated hepatotoxicity risks, the potential responsible chemicals for these two activities, and the mechanisms of action. Overall, kava has a great potential to be developed as a natural anxiolytic agent through a systematic approach, but the present form should be used with caution.
\end{abstract}

Keywords: Anxiety disorders; Muscle tension; Insomnia; Treatment

\section{Introduction}

Anxiety disorders, in various forms, affect around 25 million people in the United States annually [1]. Generalized anxiety disorder is commonly characterized by persistent anxiety and frequent irrational worry that occurs consistently for at least 6 months. Anxiety disorders are often associated with depression, excessive phobia, and physical symptoms such as headache, gastrointestinal distress, muscle tension, insomnia, and others. The diagnosis of anxiety disorders usually employs screening tools, including the Generalized Anxiety Disorder 7 (GAD-7), which can be used to assess the severity of the disease and treatment progress. The diagnosis also involves screening for social anxiety disorder, which is characterized by the experience of persistent fear or worrying about social situations [2]. The diagnosed anxiety disorders fall into many different types, such as anxious depression, health anxiety, obsessive-compulsive disorder, social anxiety, and panic disorder. Though these disorders all show high rates of coexisting symptoms, they also have different nuances that separate them as unique conditions. Because of this, the clinical management of anxiety disorders has to address a complex array of psychological and physical symptoms. Treatment of anxiety disorders often includes lifestyle modifications, psychotherapy, pharmacotherapy or a combination of these.

Pharmacotherapy of anxiety disorders, as outlined in guidelines of World Foundation for Biological Psychiatry [3], uses a number of different classes of medications. These range from pure anxiolytics like gamma-Aminobutyric acid (GABA) agonists including benzodiazepines, serotonin-reuptake inhibitors (SSRIs) and serotoninnorepinephrine reuptake inhibitors (SNRIs), antidepressants, and antihistamines [4]. While generally effective, these medications are not without risks, as some are addictive, most interact with alcohol, and some can even increase anxiety in certain patients. More specifically, benzodiazepines are associated with several adverse effects, including increased sedation, interactions with ethanol, and a potential of addiction. Serotonin or norepinephrine modulating therapies have a long latency period, and in some cases can increase anxiety, cause headaches, and may have withdrawal symptoms. The tricyclics come with the same somnolence issue as benzodiazepines, can produce weight gain, and can be lethal if consumed in excess. Finally, antihistamines such as hydroxyzine also have significant issues, including sedation and anticholinergic effects [5]. Because of these risks, patients are turning to products that are categorized as "herbal" or "natural", assuming that these products are generally safer, and a better option to treat their conditions than a prescription drug. Kava is one such natural product that has been used in the treatment of anxiety disorders.

Traditional kava is an aqueous extract of the roots and rhizomes of Piper methysticum, a tropical shrub indigenous to the islands of the South Pacific. Fresh or dried roots are crushed into a powder and rehydrated into the kava beverage, which is consumed in both social and ceremonial manners. Kava has occupied an important place in the day-to-day culture in the South Pacific islands with the first document from 1777 showing its use as a drink [6]. It has also been used by the native islanders to treat venereal diseases, rheumatism and asthma, to counteract fatigue as well as to reduce pain and fever [7]. The reported effect of traditional kava ranges from peaceful relaxation to sedation $[7,8]$, and because of this, its use as a natural alternative to pharmacotherapy for anxiety spread worldwide in the late $20^{\text {th }}$ century [9]. With its wide spread usage and lack of rigorous quality control of various products, reports about kava's hepatotoxic risk began to surface, prompting a number of countries to ban it as a clinical anxiolytic. As further research explored the cause of hepatotoxicity [10] and its anxiolytic potential $[11,12]$, there has been a renewed interest in exploring kava as a novel treatment for anxiety and its ban has been lifted in Germany. This review article focuses on therapeutic properties of kava in controlled anxiolytic trials, its safety profile, the knowledge about the active ingredient(s) and the mechanism of action.

\section{Methods}

In order to obtain data on the role of kava in anxiety therapy, a review of PubMed, and OVID Medline databases was conducted, with the key words Kava, Kava Kava, Kawa, Piper methysticum, anxiety, and anxiolytic. Exclusion criteria were online trial design, concurrent study of other herbal compounds, single-dose trials, and trials not published in English, while inclusion criteria were clinical trials with a

*Corresponding author: Sreekanth Narayanapillai, Department of Medicina Chemistry, College of Pharmacy, University of Minnesota, 2231 6th St SE, Minneapolis, MN 55455, USA, Tel: 612-626-5543; E-mail: snarayan@umn.edu

Received January 23, 2016; Accepted February 05, 2016; Published February 09, 2016

Citation: Rivers Z, Xing C, Narayanapillai S (2016) Kava as a Pharmacotherapy of Anxiety Disorders: Promises and Concerns. Med chem 6: 081-087. doi:10.4172/2161-0444.1000329

Copyright: ( 2016 Rivers Z, et al. This is an open-access article distributed under the terms of the Creative Commons Attribution License, which permits unrestricted use, distribution, and reproduction in any medium, provided the original author and source are credited. 
primary efficacy endpoint involving reduction in anxiety. In addition, structure, function, and mechanism of action were also added to the search criteria to explore the literature for possible explanations for kava's mechanism of action related to anxiolysis. Finally, liver, liver enzymes, liver failure, hepatotoxicity, and rash were added to screen for publications that discuss the possible harms of kava.

\section{Anxiolytic trials using kava extracts}

There have been a number of randomized clinical trials that evaluated kava's anxiolytic potential as specific extracts of the plant. These studies are summarized in Table 1 . One subset of these trials examined the use of WS1490, a kava extract with high kavalactone content, in both short term and long-term settings. These trials were carried out in a placebo controlled, double-blinded manner, and used the same scoring system, the Hamilton Anxiety Scale (HAMA), to measure efficacy. Though these were two small trials, with 58 participants enrolled in one [13], and 101 enrolled in the other [14], they demonstrate some of the strongest evidence for the use of kava as an anxiolytic agent. Interestingly, the 4 week short term trial showed a statistically significant improvement over the placebo [13], while the longer 25 week trial didn't show any significant difference between the two arms until eight weeks into the trial [14]. This discrepancy could be the small sample size in these trials.
This specific kava product, WS1490, was further examined in another randomized, double blind, placebo controlled trial with 40 patients enrolled [15]. In this study, subjects taking benzodiazepines were enrolled and they were screened to ensure that they had no other psychotic comorbidities, including depression. At the initiation of the trial, patients were titrated up from $50 \mathrm{mg}$ of standardized kava extract to $300 \mathrm{mg}$, as their benzodiazepine dose was titrated down, with a goal of no benzodiazepine usage after two weeks. The kava arm was found to have a median decrease of 7.5 points on a HAMA scale of 56 , or approximately 13 percent, while the placebo arm actually increased an average of 1 point. The study also included a crossover arm after completion, where patients who were in the WS1490 arm were switched to placebo, and reported that $64 \%$ of the patients that crossed over had recurring anxiety symptoms on the placebo. Finally, no adverse effects were reported by patients, nor were any blood work abnormalities found, including liver functions. Another blinded placebo controlled trial was also conducted to determine whether WS1490 at the dose of $150 \mathrm{mg}$ per day was effective when compared to a placebo [16]. In this multi-center study, different clinicians assessed patients using a largely subjective scale, and the primary outcome measure was shifted from HAMA to the Anxiety Status Inventory. There was no difference in the primary endpoint at the six-week conclusion of this trial, which could

\begin{tabular}{|c|c|c|c|c|c|c|c|}
\hline Year & $\begin{array}{l}\text { Duration } \\
\text { (weeks) }\end{array}$ & $\begin{array}{l}\text { Number of } \\
\text { enrollment }\end{array}$ & Therapy & Comparator & Primary Endpoint & Secondary endpoint & Outcomes \\
\hline 1996 [13] & 4 & 58 & $\begin{array}{l}\text { WS } 1490,100 \mathrm{mg} \text {, three } \\
\text { times daily }\end{array}$ & Placebo & $\begin{array}{l}\text { HAMA scale compared to } \\
\text { baseline }\end{array}$ & $\begin{array}{l}\text { Adjectives Checklist } \\
\text { and Clinical Global } \\
\text { Impression Scale } \\
\text { (CGI) }\end{array}$ & $\begin{array}{l}\text { Significant reduction in } \\
\text { HAMA after one week, } \\
\text { continued to widen over } \\
\text { the trial }\end{array}$ \\
\hline 1997 [14] & 25 & 101 & $\begin{array}{c}\text { WS } 1490,100 \mathrm{mg} \text {, three } \\
\text { times daily }\end{array}$ & Placebo & $\begin{array}{l}\text { HAMA scale compared to } \\
\text { baseline }\end{array}$ & $\begin{array}{l}\text { Adjectives Checklist } \\
\text { and CGI }\end{array}$ & $\begin{array}{l}\text { Significant reduction in } \\
\text { HAMA, but not until } 8 \text { weeks }\end{array}$ \\
\hline 2001 [15] & 5 & 40 & $\begin{array}{l}\text { WS } 1490,100 \mathrm{mg} \text {, three } \\
\text { times daily }\end{array}$ & Placebo & $\begin{array}{l}\text { HAMA scale compared to } \\
\text { baseline, Benzodiazipine } \\
\text { withdrawal symptoms }\end{array}$ & $\begin{array}{l}\text { Erlanger Anxiety, } \\
\text { Tension and } \\
\text { Aggression Scale } \\
\text { (EAAS) and CGI }\end{array}$ & $\begin{array}{c}\text { Significant reduction in } \\
\text { HAMA }\end{array}$ \\
\hline $2001[17]$ & 25 & 40 & $\begin{array}{c}100 \mathrm{mg} \text { (55\% kavain), } \\
\text { once daily + HRT }\end{array}$ & Placebo + HRT & $\begin{array}{l}\text { HAMA scale compared to } \\
\text { baseline }\end{array}$ & $\mathrm{N} / \mathrm{A}$ & $\begin{array}{l}\text { Significant decrease } \\
\text { compared to baseline and } \\
\text { placebo +HRT arms }\end{array}$ \\
\hline 2003 [18] & 12 & 68 & $\begin{array}{c}100 \mathrm{mg} \text { or } 200 \mathrm{mg}(55 \% \\
\text { kavain), once daily }\end{array}$ & No therapy & $\begin{array}{l}\text { State-Trait Anxiety } \\
\text { Inventory }\end{array}$ & $\mathrm{N} / \mathrm{A}$ & $\begin{array}{l}\text { Significant decrease in } \\
\text { anxiety }\end{array}$ \\
\hline 2001 [19] & 4 & 13 & $\begin{array}{c}280 \mathrm{mg} \mathrm{(30 \%} \\
\text { kavalactones), daily }\end{array}$ & Placebo & $\begin{array}{l}\text { Baroreflex control of heart } \\
\text { rate and respiratory sinus } \\
\text { arrhythmia }\end{array}$ & $\begin{array}{l}\text { Global Improvement } \\
\text { Score by clinicians }\end{array}$ & $\begin{array}{l}\text { Significant increase in BRC, } \\
\text { but no change in RSA }\end{array}$ \\
\hline 2002 [20] & 4 & 37 & $\begin{array}{c}\text { Kavalactones } 70 \mathrm{mg} \text { twice } \\
\text { daily for one week, then } \\
\text { titrated up to } 140 \mathrm{mg} \text { twice } \\
\text { daily }\end{array}$ & Placebo & $\begin{array}{l}\text { HAMA scale compared } \\
\text { to baseline, Hospital } \\
\text { Anxiety and Depression } \\
\text { Scale, Self-Assessment of } \\
\text { Resilience and Anxiety }\end{array}$ & $\mathrm{N} / \mathrm{A}$ & No significant difference \\
\hline 2003 [21] & 8 & 129 & $\begin{array}{c}400 \text { mg of kava extract } \\
\text { once daily ( } 30 \% \\
\text { kavapyrone) }\end{array}$ & $\begin{array}{c}5 \mathrm{mg} \text { of Buspirone } \\
\text { twice daily or } 50 \\
\text { mg of opipramol } \\
\text { twice daily }\end{array}$ & $\begin{array}{l}\text { HAMA scale compared to } \\
\text { baseline }\end{array}$ & $\begin{array}{l}\text { Boerner Anxiety Scale, } \\
\text { von Zersen Mood } \\
\text { Scale, CGI, Zung Self- } \\
\text { Rating Anxiety Scale }\end{array}$ & $\begin{array}{l}\text { Significant decrease in } \\
\text { HAMA scores }\end{array}$ \\
\hline 2003 [16] & 6 & 141 & $\begin{array}{l}\text { WS } 1490,50 \mathrm{mg} \text {, three } \\
\text { times daily }\end{array}$ & Placebo & $\begin{array}{l}\text { Anxiety Status Inventory } \\
\text { (ASI) }\end{array}$ & $\begin{array}{l}\text { BF-S, CGI, EAAS, } \\
\text { Knowledge of Effective } \\
\text { Parenting Scale }\end{array}$ & $\begin{array}{c}\text { No difference between } \\
\text { placebo and drug, significant } \\
\text { difference between } \\
\text { beginning and end ASI in } \\
\text { treatment group }\end{array}$ \\
\hline 2009 [22] & 3 & 60 & $\begin{array}{l}\text { Standardized to } \\
\text { kavalactones }(250 \mathrm{mg}) \\
\text { divided into } 5 \text { pills daily }\end{array}$ & Placebo & $\begin{array}{l}\text { HAMA scale compared to } \\
\text { baseline }\end{array}$ & $\begin{array}{c}\text { Beck Anxiety } \\
\text { Inventory, } \\
\text { Montgomery-Asberg } \\
\text { Depression Rating } \\
\text { Scale }\end{array}$ & $\begin{array}{l}10.1 \text { point decrease on } \\
\text { HAMA scale, } p<0.0001\end{array}$ \\
\hline $2013[11]$ & 6 & 75 & $\begin{array}{l}\text { Standardized to } \\
\text { kavalactones ( } 60 \mathrm{mg}) \text {, } \\
\text { twice daily; titrated to } 120 \\
\text { mg twice daily at } 3 \text { weeks }\end{array}$ & Placebo & $\begin{array}{l}\text { HAMA scale compared to } \\
\text { baseline }\end{array}$ & $\mathrm{N} / \mathrm{A}$ & $\begin{array}{l}\text { Significant decrease on } \\
\text { HAMA scale, } p<0.0001 \text {. }\end{array}$ \\
\hline
\end{tabular}

Table 1: The summary of kava clinical trials. 
be due to the lower dose or shorter duration of the study. Of note, no significant changes in liver function were noted in this trial as well.

Kava's potential in the treatment of anxiety due to menopause was also examined [17]. Anxiety can be a common condition during menopause, as the estrogen level is rapidly changing. Previous literature reported the efficacy of hormone replacement in alleviating symptoms of anxiety associated with menopause. This study was a four-arm trial examining the impact of the addition of a kava extract to hormone replacement therapy in the treatment of menopause-associated anxiety [17]. The four-arm design was necessary due to the differing hormonal needs of women with intact reproductive systems who naturally entered menopause, versus those who entered menopause surgically. The kava regimen used in this trial consisted of $100 \mathrm{mg}$ tablets with $55 \%$ kavain taken once daily. The HRT + kava group had greater decrease in HAMA scores, $54.4 \%$ vs. $24.2 \%$ in comparison to the HRT group. These results clearly indicated that the addition of kava provided a beneficial increase in the control of anxiety without any adverse effects.

Efficiency of kava against perimenopausal anxiety was also examined in an open label, non-placebo trial with three arms [18]. All three arms received calcium supplementation, and the first arm received no other treatment, the second received normal treatment plus $100 \mathrm{mg}$ of kava extract daily, and the third arm received normal treatment plus $200 \mathrm{mg}$ of kava extract daily. In this trial, the kava product contained $55 \%$ kavain. Changes in anxiety were measured using the STAI scale, a self-administered inventory that ranges in score from 20 to 80 . In both kava arms, a statistically significant decrease in STAI scores was observed at both one and three months when compared to baseline, while the negative control arm has no significant decrease. Two patients withdrew due to adverse effects, one in each kava arm. However, they had no changes in liver enzyme levels.

In addition to causing patients significant mental stress, anxiety is also known to trigger pathophysiological effects, including elevated heart rate. These effects may be correlated with an increased risk of nonfatal myocardial infarctions and fatal coronary heart disease; however, the potential of kava to manage these symptoms has not been thoroughly tested. One study explored kava's calming effect on the cardiac pathology of anxiety [19]. This study was quite small, with 13 patients originally enrolled, and randomized to placebo or kava treatment group, with one patient from each group being excluded from the final analysis due to hypertension. This double-blind, placebo controlled trial ran for four weeks, and the parameters examined were respiratory sinus arrhythmia (RSA) and baroreceptor reflex control (BRC), which have been employed to indicate vagal cardiac control, a further surrogate for decreased risk of cardiac pathology associated with anxiety. There was a statistically significant increase in BRC with four of the six patients receiving kava experienced an increase in BRC, versus only one in the placebo arm. However, there was no difference in RSA improvement between both arms and was attributed to possible errors in data collection.

Interestingly, in another placebo controlled double blinded trial, kava did not show any difference when compared to placebo in the short-term treatment of anxiety [20]. This was a short term, 4 weeks long trial that enrolled 38 patients, with the majority of them being female. The treatment arm received kava, standardized to $70 \mathrm{mg}$ of kavalactones, twice daily for one week, and then doubled the dose for the remainder of the trial. In this study, multiple surveys were used to assess the control of anxiety, including the HAMA. While improvement was noted in both arms on the HAMA, there was a non-significant difference between them. It is interesting to note that this is the first randomized controlled trial that notes transient liver enzyme elevation, though one of the subjects was mentioned to be already predisposed to elevated liver function tests. In addition, the findings of this study are similar to those in the first long WS1490 trial, conducted by Volz et al. in that there was no significant difference at four weeks [14].

Investigational therapies are also frequently compared to standard treatments rather than placebo. A kava extract standardized to 120 mg kavalactone was compared to $5 \mathrm{mg}$ buspirone twice daily, or 50 mg opipramol twice daily, an anxiolytic that is not approved for use in the United States [21]. This was a double blinded trial, and lasted for 8 weeks, with a ninth week-off of medications to assess withdrawal symptoms. 119 patients were enrolled with a diagnosis of only general anxiety disorder, and excluded a variety of other mental health conditions. Efficacy was assessed using the HAMA scale, and all three arms displayed a significant decrease in HAMA scores, both at 2 weeks and 8 weeks, indicating that kava may have an early onset of action, and that they are just as effective as current therapies for treating anxiety.

In the early 2000s, case reports of hepatotoxicity began to surface, causing the interest in kava for anxiety treatment to decrease. These case reports are discussed in a later section, but prompted a study of a whole-plant aqueous extract for anxiety [22]. This trial was performed to assess the anxiolytic properties of the aqueous extract with 60 patients enrolled and the duration of three-week kava treatment. Patients, excluded if they had any elevated liver enzymes, were randomized into placebo or kava extract treatment group. Both groups were given placebo for one week and individuals were excluded from the active portion of the trial if they showed a greater than $50 \%$ improvement on the HAMA after the one-week placebo treatment, a technique used to eliminate false responders. The results of the study showed that this novel kava extract was effective in managing anxiety, with a mean decrease of 10.1 points on the HAMA scale in the treatment arm over the placebo arm. The kavalactone content in the new extract in this study was established, and the daily dose of kavalactones was found to be comparable to what had been reported in previous trials. Sarris et al. continued to explore the anxiolytic effect of the aqueous extract with a second trial [11]. In this trial, 75 participants were enrolled, with nine being excluded after a one-week placebo response period, again used to eliminate false responders. Participants in this trial started on the aqueous kava extract standardized to $120 \mathrm{mg}$ of kavalactones daily for the first three weeks, with a clinician's option to titrate up to 240 $\mathrm{mg}$ at 3 weeks among the non-responders. This was mirrored in the placebo arm, by doubling the number of placebo pills taken in the nonresponders. At the end of the 6-week active drug trial, there was also a week long washout period, allowing the investigators to examine the withdrawal effects of the active drug. At the end of the trial, there was a significant reduction in HAMA scores in the kava extract arm when compared to the placebo. Due to the increasing concerns of kava's possible hepatotoxicity, which is addressed later, all participants in the trial were screened at three different times for elevated liver enzymes, and there were no statistically significant differences between enzymes levels during this trial.

In addition, a meta-analysis conducted in 2011 examined the neurocognitive side effects of kava in a variety of clinical trials [23]. 10 trials were selected for inclusion in this analysis, and the authors found that kava had no negative neurocognitive effects when used to manage acute conditions. As mentioned earlier in this review, patients often turn to naturally derived products in order to avoid side effects, so the lack of impairment seen with kava when compared to medications like benzodiazepines may make it a more attractive therapeutic option for patients. 


\section{Kava's chemical composition and the potential anxiolytic compound(s)}

Similar to any natural extract, kava contains a number of constituents, whose composition depends on a number of factors, including the cultivars, the culture conditions, the parts of the plant used, and the methods of extraction. Numerous methods have also been developed to characterize the chemical composition of kava products, such as the recent HLPC-based method [24], the HPTLC-based method [25], and the LC-MS based method [26]. Generally kava extracts contain several classes of chemicals, including kavalactones, flavones, chalcones and many others. Some of these constituents are shown in Figure 1. Kavalactones are typically the characteristic constituents, including yangonin, desmethoxyyangonin, kavain, dihydrokavain, methysticin, and dihydromethysticin. These kavalactones, particularly kavain, are believed to be responsible for kava's anxiolytic activity [27]. The total content of these kavalactones, therefore, has been used for the standardization of kava extracts as discussed in the kava trials. Despite their high structural similarity, they could elicit distinct molecular changes [28], suggesting that they would have different contribution to kava's anxiolytic activity. Two small-scale clinical trials in the early 1990s evaluated and demonstrated the anxiolytic activity of kavain $[29,30]$. These studies, however, did not evaluate kava or any other kavalactones for efficacy comparison, which would be necessary to determine whether kavain is the major anxiolytic in kava. Surprisingly, there have been only two in vivo studies to identify the anxiolytic compound(s) in kava and both studies speculated that dihydrokavain might be the active candidate [31,32] although the assay used (chick social separation-stress paradigm) is not one of the standard anxiolytic assays [33]. Therefore the anxiolytic ingredient(s) in kava remains to be firmly validated, which is critical for kava's standardization and future clinical development of kava-based effective anxiolytics.

\section{Kava's anxiolytic mechanisms}

As kava's anxiolytic translational development was largely based on its established and widespread traditional use to promote relaxation, no target identification occurred as it transitioned to a more widespread prescribed usage. It is also very difficult to elucidate the mechanism of action for kava because of its mixture nature with varied abundance among different products. Effort had been undertaken by different research groups to identify both the active compounds in kava as well as their sites of action, mostly based on biochemical and cell-based assays. As mentioned earlier, there are many different pharmaceutical compounds used to manage and treat anxiety disorders, and the site of action of those compounds were examined as possible targets for kava. One group used kavain in a rat neuronal model and suggested that this possible active ingredient likely acted through an anti-convulsant pathway [34]. Similar to gabapentin and pregabalin, kavain was found to modulate calcium channels, reducing the activity of voltage gated calcium channels. In addition to acting on calcium channels, this group found that kavain also acted on voltage gated sodium channels, reducing their activity. This finding reinforces data from a previous study, again using a cell-based rat model, which found that kavain inhibits voltage gated sodium channels, slowing the neuronal activity [35]. While these studies provide an important framework in shaping the understanding of kava's mechanism of action, they both were conducted in vitro with a single kava-derived compound, limiting their applicability to understanding the anxiolytic action in humans.

The benzodiazepine class of medications exert their anxiolytic effect by binding to the GABA(a) receptor in the central nervous system. This serves to open chloride channels, hyperpolarizing the cell membrane, and increasing the threshold for activity. A number of investigators have examined the GABA-modulating role of kava or kava-derived compounds in vitro and ex vivo [36]. It was found that a number of kava constituents inhibited benzodiazepine binding in rat forebrains, via an in vitro model, but when the compounds were translated to ex vivo murine models, they had no activity. In order to confirm these findings, a controlled in vivo receptor-displacement experiment was conducted with radiolabeled [H3] GABA. Mice were injected with the radiolabeled GABA, and after an incubation period, treated with either a kava<smiles>COc1cc(/C=C/c2ccc(OC)c(OC)c2)oc(=O)c1</smiles>

11-Methoxyyangonin<smiles>COc1cc(/C=C/c2ccccc2)oc(=O)c1</smiles>

Desmethoxyyangonin<smiles>COc1cc(CCc2ccccc2)oc(=O)c1</smiles>

(+)-Dihydrokavain<smiles>COC(=O)C1=CC(OC)OC(/C=C/c2ccccc2)C1</smiles>

(+)-Kavain<smiles>COc1cc(CCc2ccc3c(c2)OCO3)oc(=O)c1</smiles>

$(+)-$ Dihydrom ethysticin<smiles>COc1ccc([C@H]2CC(=O)c3c(O)cc(OC)cc3O2)cc1</smiles><smiles>COC1C=C(C)C(/C=C/c2ccc3c(c2)OCO3)OC1=O</smiles>

(+)-Methysticin<smiles>CC1C(OC(=O)/C=C/c2ccc3c(c2)OCO3)C2CCC1C2(C)C</smiles>

Bornyl esters of 3,4-methylenedioxy cinnamic acid<smiles>COc1cc(O)c(C(=O)/C=C/c2ccccc2)c(O)c1</smiles>

Flavokawain B<smiles>COc1ccc(/C=C/c2c(O)cc(O)cc2O)c(O)c1</smiles>

Flavokawain A<smiles>COc1cc(O)c(OC)c(C(=O)/C=C/c2ccc(O)cc2)c1</smiles>

Flavokawain C

Figure 1: The structures of representative chemicals identified in kava 
extract or a benzodiazepine, and then sacrificed. The amount of labeled compound displaced by each treatment was measured, and used as an indicator of the affinity for the receptor by the treatment. There was no displacement by the kava extract, and nearly complete displacement by the benzodiazepine, indicating that the GABA receptor is not a likely target for kava, nor the source of its pharmacological action.

Grunze et al. discussed three different in vitro experiments to further explore mechanisms for kava's anxiolytic properties [37]. The first explored GABAergic properties of kava in guinea pig hippocampal slices and it did not show the stereotypical positive movement as seen by GABA or GABA agonists. This study showed that kava might function in the serotonergic pathway as well as in the glutamanergic pathway. Other experiments conducted by these investigators further reinforced the concept that kavain antagonizes $\mathrm{Ca}^{2+}$ channels, and has effects on sodium and potassium channels, similar to those of mood stabilizing and anti-epileptic therapies. However, there was not in vivo validation of these results.

The mechanism of action of kava was also explored in comparison with other anxiolytic therapies such as serotonin and norepinephrine reuptake inhibitors. Cerebrocortical and hippocampal synaptisomes of rats were used to assess the possible monoamine-modulating effects that kava may have [38]. After applying norepinephrine and serotonin to the cells, kava extracts were given, and the effect of reuptake inhibition was measured, as seen by the amount of neurotransmitter not taken up by the cells. These values were compared to the effect of a known norepinephrine reuptake inhibitor, desimpiramine, and a known serotonin reuptake inhibitor, fluoxetine. When compared to the inhibition curves demonstrated by the known inhibitors, kava favorably resembled the norepinephrine inhibitor, but showed minimal serotonin reuptake inhibition. This study suggests that kava may act similarly as norepinephrine reuptake inhibitors in providing an anxiolytic effect. Again, this has not been validated in vivo as well.

\section{Kava's hepatotoxic risk}

General populations who choose to use kava for anxiety relief may view it as a safer alternative to the current pharmacotherapies; however, over the past few decades, a number of adverse case reports were published, raising the concern that kava may not be as harmless as it was originally thought. Kava has been reported to be associated with hepatotoxicity and dermatitis-like reactions. An early account of hepatotoxicity was published in 1998, as a case report of one patient who was admitted with elevated ALT, and biopsy proven acute necrotizing hepatitis, after ingestion of kava. The clinicians decided to hold her kava therapy, and according to the report, her liver function rapidly normalized [39]. Another case report came from a different group, and described the case of a 42-year-old woman who had taken an unknown amount of kava over a two-week period and presented with elevated levels of serum biomarkers for liver damage [40]. Similar cases of kava related hepatotoxicity was reported from South Pacific [41], Germany [10,42], Australia [43], and USA [44,45]. Following these reports, there was a significant global concern on its safety, and resulted in its withdrawal from European markets [46,47]; and many countries released consumer advices to caution people kava usage [48].

Recently the World Health Organization has revisited most of the kava-associated hepatotoxicity cases [49], analyzing the potential causes, providing guidance for the safe use of kava, and making recommendation for further studies to identify the actual hepatotoxic compounds. The report indicated alcohol usage, cytochrome P450 enzyme polymorphisms, and previous liver disease as potential risk factors. The organic extracts of kava may include toxic compounds not found in aqueous extracts, and suggested that synthetic compounds and aqueous extracts may be a safer choice. It was also recommended to maintain good manufacturing practices in the production of kava, regarding strain selection, usage of specific parts of the plant and methods of preparation. In addition, $\sim 90 \%$ of the purported kava hepatotoxic cases consumed other medications or dietary supplements [49], suggesting potential herb-drug interactions.

A commercial kava product was recently demonstrated to synergize the hepatotoxic risk of acetaminophen in C57BL/6 mice and chalcone-based flavokavain A and flavokavain B, not the kavalactones, were identified as the responsible chemicals [50]. These chalconebased flavokavains are highly abundant in the ethanolic kava extracts while their contents in the aqueous kava extract are typically order of magnitude lower if not undetectable [26].

Mechanistically a number of hypotheses have been formulated with respect to kava associated hepatotoxic risk [51]. The cytochrome P450 (CYP) pathway has been the focus, because CYP enzymes are common drug metabolizing enzymes. Different isoforms are capable of recognizing and metabolizing different molecules, and are susceptible to induction and inhibition by a variety of substances. The inhibition of CYP pathways can induce drug-drug interactions, drug-herb interactions, as well as drug-patient interactions. Therefore kava's effects on the CYP pathway have been closely examined. In an attempt to isolate the specific hepatotoxic compound from kava, a variety of individual compounds and their effects on cDNA-expressed human CYP enzymes, as well as hepatocytes, were examined and it was found that yangonin, desmethoxyyangonin and methysticin can inhibit several CYP enzymes [52]. In another study, one aqueous kava extract, one ethanolic extract, and one commercially available product were evaluated. Four CYP isoforms (3A4, 1A2, 2C9, and 2C19) were found to be inhibited more by the ethanolic and commercial preparations than the aqueous preparation [53], suggesting higher abundance of the hepatotoxic compound in the ethanolic extract relative to the aqueous extract. Their physiological relevance however remains to be tested in in vivo models. Other theories for kava-induced liver damage include the formation of electrophilic quinoid metabolites from kava constituents in the liver [51,54], usage of wrong plant parts to prepare the extract $[55,56]$, and kava contamination by Aspergillus species producing mycotoxins $[57,58]$.

It should also be noted that despite the ban of kava in European countries, aqueous and organic solvent based kava products remain over the counter in Australia and New Zealand [22,49]. The manufacturing and usage of kava products were never restricted in the U.S.A. as well [59]. The German administrative court recently lifted the decade old "ban" of all kava-containing medicinal preparations and ruled that the available data do not support the alleged hepatotoxicity $[60,61]$. Also, there is a likely causal association of elevated gamma glutamyl transpeptidase levels when aqueous kava extracts are consumed, however there are no literature evidence suggestingdirect or irreversible hepatotoxic effect of aqueous kava extracts [62].

\section{Conclusions}

Kava, from an anxiolytic efficacy standpoint, show promising results in 10 out of the 11 randomized controlled trials with a tolerable side-effect profile. However, when used in the non-clinical trial setting, there is a concern of side effects including liver toxicity, which has a higher chance of drug-drug and drug-herb interactions in comparison to the more regulated clinical trials. To enable kava's transition from a dietary supplement to an essential anxiolytic agent, further work needs to be done to identify the active principles and its mechanisms 
of action, which would help guide the best clinical use. In addition, the hepatotoxic components need to be eliminated, which would significantly improve its safety profile.

\section{References}

1. Parekh R (2015) Help with anxiety disorders.

2. American Psychiatric Association (2013) DSM-5 Task Force. Diagnostic and statistical manual of mental disorders: DSM-5. 5th edn. Washington, D.C.: American Psychiatric Association.

3. Bandelow B, Sher L, Bunevicius R, Hollander E, Kasper S, et al. (2012) Guidelines for the pharmacological treatment of anxiety disorders, obsessivecompulsive disorder and posttraumatic stress disorder in primary care. Int $\mathrm{J}$ Psychiatry Clin Pract 16: 77-84.

4. Stein MB, Sareen J (2015) Clinical Practice. Generalized Anxiety Disorder. N Engl J Med 373: 2059-2068.

5. Julien RM, Advokat CD, Comaty JE (2010) A primer of drug action: a comprehensive guide to the actions, uses and side effects of psychoactive drugs. 12th edn. New York, NY: Worth Publishers.

6. (2015) The benefits of the use of Kava Kava in herbal preparations: History of Kava Kava.

7. Singh YN (1992) Kava: an overview. J Ethnopharmacol 37: 13-45.

8. Singh YN, Singh NN (2002) Therapeutic potential of kava in the treatment of anxiety disorders. CNS Drugs 16: 731-743.

9. Finau SA, Stanhope JM, Prior IA (1982) Kava, alcohol and tobacco consumption among Tongans with urbanization. Soc Sci Med 16: 35-41.

10. Teschke R, Schwarzenboeck A, Hennermann KH (2008) Kava hepatotoxicity: a clinical survey and critical analysis of 26 suspected cases. Eur J Gastroenterol Hepatol 20: 1182-1193.

11. Sarris J, Stough C, Bousman CA, Wahid ZT, Murray G, et al. (2013) Kava in the treatment of generalized anxiety disorder: a double-blind, randomized, placebo-controlled study. J Clin Psychopharmacol 33: 643-648.

12. Sarris J, Stough C, Teschke R, Wahid ZT, Bousman CA, et al. (2013) Kava for the treatment of generalized anxiety disorder RCT: analysis of adverse reactions, liver function, addiction, and sexual effects. Phytother Res 27: 17231728.

13. Lehmann E, Kinzler E, Friedemann J (1996) Efficacy of a special Kava extract (Piper methysticum) in patients with states of anxiety, tension and excitedness of non-mental origin - A double-blind placebo-controlled study of four weeks treatment. Phytomedicine 3: 113-119.

14. Volz HP, Kieser M (1997) Kava-kava extract WS 1490 versus placebo in anxiety disorders--a randomized placebo-controlled 25-week outpatient trial. Pharmacopsychiatry 30: 1-5.

15. Malsch U, Kieser M (2001) Efficacy of kava-kava in the treatment of non-psychotic anxiety, following pretreatment with benzodiazepines. Psychopharmacology (Berl) 157: 277-283.

16. Gastpar M, Klimm HD (2003) Treatment of anxiety, tension and restlessness states with Kava special extract WS 1490 in general practice: a randomized placebo-controlled double-blind multicenter trial. Phytomedicine 10: 631-639.

17. De Leo V, la Marca A, Morgante G, Lanzetta D, Florio P, et al. (2001) Evaluation of combining kava extract with hormone replacement therapy in the treatment of postmenopausal anxiety. Maturitas 39: 185-188.

18. Cagnacci A, Arangino S, Renzi A, Zanni AL, Malmusi S, et al. (2003) KavaKava administration reduces anxiety in perimenopausal women. Maturitas 44 : 103-109.

19. Watkins LL, Connor KM, Davidson JR (2001) Effect of kava extract on vagal cardiac control in generalized anxiety disorder: preliminary findings. $J$ Psychopharmacol 15: 283-286.

20. Connor KM, Davidson JR (2002) A placebo-controlled study of Kava kava in generalized anxiety disorder. Int Clin Psychopharmacol 17: 185-188.

21. Boerner RJ, Sommer H, Berger W, Kuhn U, Schmidt U, et al. (2003) KavaKava extract LI 150 is as effective as Opipramol and Buspirone in Generalised Anxiety Disorder--an 8-week randomized, double-blind multi-centre clinical trial in 129 out-patients. Phytomedicine 10: 38-49.
22. Sarris J, Kavanagh DJ, Adams J, Bone K, Byrne G (2009) Kava Anxiety Depression Spectrum Study (KADSS): a mixed methods RCT using an aqueous extract of Piper methysticum. Complement Ther Med 17: 176-178.

23. LaPorte E, Sarris J, Stough C, Scholey A (2011) Neurocognitive effects of kava (Piper methysticum): a systematic review. Hum Psychopharmacol 26: 102-111.

24. Gaub M, von Brocke A, Roos G, Kovar KA (2004) High-performance liquid chromatography-coordination ion spray-mass spectrometry (HPLC-CIS/MS): a new tool for the analysis of non-polar compound classes in plant extracts using the example of Piper methysticum Forst. Phytochem Anal 15: 300-305.

25. Lebot $V$, Do TK, Legendre $L$ (2014) Detection of flavokavins (A, B, C) in cultivars of kava (Piper methysticum) using high performance thin layer chromatography (HPTLC). Food Chem 151: 554-560.

26. Martin AC, Johnston E, Xing C, Hegeman AD (2014) Measuring the chemical and cytotoxic variability of commercially available kava (Piper methysticum G. Forster). PLoS One 9: e111572.

27. Gounder R (2006) Kava consumption and its health effects. Pac Health Dialog 13: $131-135$

28. Baum SS, Hill R, Rommelspacher H (1998) Effect of kava extract and individual kavapyrones on neurotransmitter levels in the nucleus accumbens of rats. Prog Neuropsychopharmacol Biol Psychiatry 22: 1105-1120.

29. Lindenberg D, Pitule-Schodel H (1990) D,L-kavain in comparison with oxazepam in anxiety disorders. A double-blind study of clinical effectiveness. Fortschr Med 108: 49-50.

30. Lehmann E, Klieser E, Klimke A, Krach H, Spatz R (1989) The efficacy of Cavain in patients suffering from anxiety. Pharmacopsychiatry 22: 258-262.

31. Feltenstein MW, Lambdin LC, Ganzera M, Ranjith H, Dharmaratne W, et al (2003) Anxiolytic properties of Piper methysticum extract samples and fractions in the chick social-separation-stress procedure. Phytother Res 17: 210-216.

32. Smith KK, Dharmaratne HR, Feltenstein MW, Broom SL, Roach JT, et al (2001) Anxiolytic effects of kava extract and kavalactones in the chick social separation-stress paradigm. Psychopharmacology (Berl) 155: 86-90.

33. Haller J, Alicki M (2012) Current animal models of anxiety, anxiety disorders, and anxiolytic drugs. Curr Opin Psychiatry 25: 59-64.

34. Schirrmacher K, Büsselberg D, Langosch JM, Walden J, Winter U, et al. (1999) Effects of (+/-)- kavain on voltage-activated inward currents of dorsal root ganglion cells from neonatal rats. Eur Neuropsychopharmacol 9: 171-176.

35. Gleitz J, Beile A, Peters T (1995) (+/-)-Kavain inhibits veratridine-activated voltage-dependent $\mathrm{Na}(+)$-channels in synaptosomes prepared from rat cerebral cortex. Neuropharmacology 34: 1133-1138.

36. Davies LP, Drew CA, Duffield P, Johnston GA, Jamieson DD (1992) Kava pyrones and resin: studies on GABAA, GABAB and benzodiazepine binding sites in rodent brain. Pharmacol Toxicol 71: 120-126.

37. Grunze H, Langosch J, Schirrmacher K, Bingmann D, Von Wegerer J et al. (2001) Kava pyrones exert effects on neuronal transmission and transmembraneous cation currents similar to established mood stabilizers--a review. Prog Neuropsychopharmacol Biol Psychiatry 25: 1555-1570.

38. Seitz U, Schule A, Gleitz J (1997) [3H]-monoamine uptake inhibition properties of kava pyrones. Planta Med 63: 548-549.

39. Strahl S, Ehret V, Dahm HH, Maier KP (1998) Necrotizing hepatitis after taking herbal remedies. Dtsch Med Wochenschr 123: 1410-1414.

40. Guro-Razuman S, Anand P, Hu Q, Mir R (1999) Dermatomyositis-like illness following kava-kava ingestion. J Clin Rheumatol 5: 342-345.

41. Russmann S, Barguil Y, Cabalion P, Kritsanida M, Duhet D, et al. (2003) Hepatic injury due to traditional aqueous extracts of kava root in New Caledonia. Eur $J$ Gastroenterol Hepatol 15: 1033-1036.

42. Teschke R (2010) Kava hepatotoxicity- a clinical review. Ann Hepatol 9: 251-265.

43. Gow PJ, Connelly NJ, Hill RL, Crowley P, Angus PW (2003) Fatal fulminant hepatic failure induced by a natural therapy containing kava. Med J Aust 178 442-443.

44. Humberston CL, Akhtar J, Krenzelok EP (2003) Acute hepatitis induced by kava kava. J Toxicol Clin Toxicol 41: 109-113.

45. Teschke R, Genthner A, Wolff A (2009) Kava hepatotoxicity: comparison of aqueous, ethanolic, acetonic kava extracts and kava-herbs mixtures. Ethnopharmacol 123: 378-384. 
Citation: Rivers Z, Xing C, Narayanapillai S (2016) Kava as a Pharmacotherapy of Anxiety Disorders: Promises and Concerns. Med chem 6: $081-087$. doi:10.4172/2161-0444.1000329

46. Moulds RF, Malani J (2003) Kava: herbal panacea or liver poison? Med J Aust 178: $451-453$

47. Teschke R, Gaus W, Loew D (2003) Kava extracts: safety and risks including rare hepatotoxicity. Phytomedicine 10: 440-446.

48. Teschke R, Sarris J, Schweitzer I (2012) Kava hepatotoxicity in traditional and modern use: the presumed Pacific kava paradox hypothesis revisited. $\mathrm{Br} \mathrm{J}$ Clin Pharmacol 73: 170-174.

49. Coulter D (2007) Assessment of the risk of hepatotoxicity with kava products. Geneva, Switzerland: World Health Organization. p: 82

50. Narayanapillai SC, Leitzman P, O'Sullivan M, Xing C (2014) Flavokawains a and B in kava, not dihydromethysticin, potentiate acetaminophen-induced hepatotoxicity in C57BL/6 mice. Chem Res Toxicol 27: 1871-1876.

51. Olsen LR, Grillo MP, Skonberg C (2011) Constituents in kava extracts potentially involved in hepatotoxicity: a review. Chem Res Toxicol 24: 992-1002.

52. Zou L, Henderson GL, Harkey MR, Sakai Y, Li A (2004) Effects of kava (Kavakava, 'Awa, Yaqona, Piper methysticum) on c-DNA-expressed cytochrome P450 enzymes and human cryopreserved hepatocytes. Phytomedicine 11: 285-294.

53. Cote CS, Kor C, Cohen J, Auclair K (2004) Composition and biological activity of traditional and commercial kava extracts. Biochem Biophys Res Commun 322: $147-152$.

54. Johnson BM, Qiu SX, Zhang S, Zhang F, Burdette JE, et al. (2003) Identification of novel electrophilic metabolites of piper methysticum Forst (Kava). Chem Res Toxicol 16: 733-740.
55. Nerurkar PV, Dragull K, Tang CS (2004) In vitro toxicity of kava alkaloid pipermethystine, in HepG2 cells compared to kavalactones. Toxicol Sci 79: 106-111.

56. Dragull K, Yoshida WY, Tang CS (2003) Piperidine alkaloids from Piper methysticum. Phytochemistry 63: 193-198.

57. Trucksess M, Weaver C, Oles C, D'Ovidio K, Rader J (2006) Determination of aflatoxins and ochratoxin $A$ in ginseng and other botanical roots by immunoaffinity column cleanup and liquid chromatography with fluorescence detection. J AOAC Int 89: 624-630.

58. Weaver CM, Trucksess MW (2010) Determination of aflatoxins in botanical roots by a modification of AOAC Official Method 991.31: single-laboratory validation. J AOAC Int 93: 184-189.

59. Teschke R, Schulze J (2010) Risk of kava hepatotoxicity and the FDA consumer advisory. JAMA 304: 2174-2175.

60. Schmidt M (2014) German court ruling reverses kava ban; German regulatory authority appeals decision. HerbalGram 103: 38-43.

61. Kuchta K, Schmidt M, Nahrstedt A (2015) German Kava Ban Lifted by Court: The Alleged Hepatotoxicity of Kava (Piper methysticum) as a Case of III-Defined Herbal Drug Identity, Lacking Quality Control, and Misguided Regulatory Politics. Planta Med 81: 1647-1653.

62. Rychetnik L, Madronio CM (2011) The health and social effects of drinking water-based infusions of kava: a review of the evidence. Drug Alcohol Rev 30: 74-83. 